\title{
"Perbedaan Efektifitas Terapi Sentuhan Dan Perawatan Metode Kanguru Terhadap Peningkatan Suhu Tubuh Bayi Berat Lahir Rendah Di RSD Idaman Kota Banjarbaru"
}

\author{
Indah Nurhayati ${ }^{\star}$, Dewi K. Wulandari..* ${ }^{\star *}$ Suroto ${ }^{\star \star *}$ \\ Email : indahnurhayti@gmail.com¹, Deik@gmail.com²
}

\begin{abstract}
ABSTRAK Bayi berat lahir rendah adalah bayi dengan berat lahir kurang dari 2500 gram. Jumlah bayi berat lahir rendah di Kalimantan Selatan tahun 2018 sebanyak 3.728 bayi. Bayi berat lahir rendah beresiko mengalami hipotermi. Hipotermi jika tidak diatasi akan menyebabkan kematian. Metode pencegahan hipotermi yang bisa dilakukan yakni perawatan metode kanguru dan terapi sentuhan. Tujuan penelitian adalah untuk mengetahui perbedaan efektifitas terapi sentuhan dan perawatan metode kanguru terhadap peningkatan suhu tubuh bayi berat lahir rendah. Penelitian ini merupakan penelitian kuantitatif dengan rancangan quasi experiment. Desain penelitian yang digunakan adalah pre test and post test designs with two comparisn treatments terhadap 30 responden, 15 responden untuk terapi sentuhan dan 15 responden untuk perawatan metode kanguru. Uji statitik yang digunakan adalah uji $t$ dependent dan independent. Hasil penelitian menunjukan ada beda efektifitas antara terapi sentuhan dan perawatan metode kanguru dalam meningkatkan suhu tubuh berat bayi lahir rendah, yaitu didapatkan $P$ value $=0,007$ dengan alpha $<0,05$. Nilai rata-rata kenaikan suhu responden perlakukan terapi sentuhan sebesar $0,17{ }^{\circ} \mathrm{C}$, sedangkan perawatan metode kanguru $0,32{ }^{\circ} \mathrm{C}$. Jadi perawatan metode kanguru terbukti lebih efektif meningkatkan suhu tubuh bayi berat lahir rendah. Dari hasil penelitian diharapkan perawatan metode kanguru bisa digunakan sebagai metode pencegahan hipotermi di pelayanan kesehatan dan dirumah.
\end{abstract}

Kata Kunci : bayi berat lahir rendah, suhu tubuh, terapi sentuhan, perawatan metode kanguru

Copyright @ 2020 Jurnal Skala Kesehatan. Politeknik Kesehatan Banjarmasin All rights reserved

Corresponding Author:

Indah Nurhayati,

Poltekkes Kemenkes Banjarmasin

Jurusan Keperawatan

Email : indahnurhayti@gmail.com 


\section{PENDAHULUAN}

Bayi berat lahir rendah adalah bayi dengan berat lahir kurang dari 2500 gram (Yunanto, 2013). Bayi berat lahir rendah merupakan salah satu masalah kesehatan masyarakat yang mendapatkan perhatian khusus, karena bayi berat lahir rendah akan menimbulkan konsekuensi jangka pendek dan panjang. Mayoritas besar, bayi berat lahir rendah terjadi di negara dengan pendapatan menengah kebawah. Prevalensi bayi berat lahir rendah di dunia pada tahun 2015 adalah 20,5 juta bayi, prevalensi di Asia sebesar $17,3 \%$ atau 12,8 juta (United Nation Children's Fund (UNICEF), 2019). Proporsi bayi berat lahir rendah di Indonesia dari tahun 2013-2018 sebesar 6.2 \% (Kementerian, 2018). Jumlah bayi berat lahir rendah di Kalimantan Selatan tahun 2017 sebanyak 3.676 bayi, kemudian naik menjadi 3.728 bayi di tahun 2018. Data di RSD Idaman Kota Banjarbaru jumlah bayi berat lahir rendah dari Januari 2018 sampai dengan Mei 2019 adalah 376 bayi.

Faktor-faktor yang mempengahuri kejadian bayi berat lahir rendah bisa dari faktor ibu, faktor janin, dan faktor plasenta. Faktor ibu karena riwayat keluarga yang melahirkan bayi prematur, status sosial ekonomi, status pendidikan, umur saat hamil, stres, depresi, merokok, kehamilan dengan body mass index rendah, infeksi, penyakit periodontal, kelainan uterus, riwayat pembedahan servik, perdarahan pervagina, kehamilan ganda, polihidramnion, servik yang pendek (Frey \& Klebanoff, 2016). Faktor janin meliputi kelainan kromosos (trisomy autosomal), infeksi janin kronik (inklusi sitomegali, rubella bawaan), disautonomia familial, radiasi, kehamilan ganda/kembar; aplasia pankreas (Proverawati \& Ismawati, 2010). Adanya microbium pada plasenta ikut serta menjadi faktor penyebab dari bayi berat lahir rendah karena gangguan aliran oksigenasi dan nutrisi ke bayi (Zheng et al., 2015).

Bayi baru lahir biasanya sangat rentan terkena hipotermia karena bayi memiliki area permukaan yang relatif besar bila dibandingkan dengan berat badan, kulit tipis dan mudah dilewati panas, memiliki lemak subkutan yang sedikit, memiliki kapasitas terbatas untuk menghasilkan panas, kemampuan untuk membentuk panas dari respon simpatik buruk, bayi prematur tidak mampu meringkukkan tubuhnnya untuk mengurangi paparan kulit (Lissauer \& Fanaroff, 2013).

Suhu tubuh merupakan keseimbangan antara produksi panas dan hilangnya panas yang sesuaikan dengan kebutuhan tubuh (Vaughans, 2013). Mekanisme fisiologis dan perilaku mengatur keseimbangan antara panas yang hilang dan dihasilkan, atau lebih sering disebut sebagai thermoregulasi. Hipotalamus mendeteksi perubahan kecil pada suhu tubuh. Hipotalamus anterior mengatur kehilangan panas, sedangkan hipotalamus posterior mengatur produksi panas (Potter, P. A., \& Perry, 2010).

Bayi-bayi yang mempunyai risiko terjadinya gangguan thermoregulasi, antara lain adalah bayi-bayi preterm dan bayi-bayi kecil, bayi-bayi dengan kelainan bawaan khususnya dengan penutupan kulit yang tidak sempurna, bayi baru lahir dengan gangguan saraf sentral, bayi dengan sepsis, bayi dengan tindakan resusitasi yang lama. Salah satu respon fisiologis bayi terhadap paparan dingin adalah dengan proses oksidasi dari lemak coklat atau jaringan adiposa coklat. Jaringan lemak coklat berisi suatu konsentrasi yang tinggi dari kandungan trigliserida, merupakan jaringan kaya kapiler dan dengan rapat diinervasi oleh syaraf simpatik yang berakhir pada pembuluh-pembuluh 
darah balik dan pada masing-masing adiposit. Suhu normal pada neonatus adalah antara 36,5 sampai $37,5^{\circ} \mathrm{C}$ (Yunanto, 2013).

Bayi yang mengalami hipotermia akan rentan terjadi vasokontriksi perifer, penurunan perfusi perifer, iskemia, asidosis metabolik, peningkatan basal metabolic rate, distres nafas, hipokalemia, peningkatan infeksi bakteri, dan gangguan pompa jantung (Farhadi, 2014). Begitu banyak bahaya yang akan timbul dari hipotermia maka semaksimal mungkin hal itu dihindari. Saat masih dalam perawatan di rumah sakit, resiko hipotermia dipantau ketat oleh perawat. Namun ketika sudah dirumah orang tua dan keluarga yang akan melakukannya jadi mereka harus diajarkan pencegahan hipotermia dirumah. Perawatan bayi berat lahir rendah dirumah untuk mencegah hipotermia adalah dengan perawatan metode kanguru (Oktiawati \& Julianti, 2017). Selain perawatan metode kanguru , terapi sentuhan pada bayi berat lahir rendah juga bisa digunakan sebagi terapi pencegahan atau penanganan hipotermia (Dieter,et.al, 2017 dalam Pongoh, 2019).

Terapi sentuhan atau pijat bayi berat lahir rendah adalah melakukan pemijatan dengan gerakan yang harus lambat dan lembut, tetapi jangan terlalu halus sehingga terasa seperti menggelitik. Pijat ini memberikan rangsangan raba (tactile stimuli) dan rangsangan kinestetik (kinestetic stimuli) yang enam kali pada setiap bagian (Roesli, 2010). Terapi sentuhan yang diaplikasikan secara sistematis disebut dengan pijat, pijat bayi diharapkan bisa menurunkan tingkat stres, meningkatkan pertumbuhan dan berkembangan bayi berat badan lahir rendah (Kaushik, 2010). Setiap gerakan dikerjakan 6 kali pada setiap bagian. Urutan pijat bayi berat lahir rendah yaitu pertama memberikan rangsangan raba (tactile stimuli) selama 5 menit, kedua memberikan rangsangan kinestektik (kenistetic stimuli) selama 5 menit, dan ketiga memberi rangsangan raba (tactile stimuli) selama 5 menit (Roesli, 2010). Peningkatan suhu terjadi pada bayi yang mendapatkan terapi sentuhan karena terjadi perpindahan panas secara konduksi melalui sentuhan tangan pemberi pijatan sehingga menurunkan kehilangan panas, memfasilitasi regulasi suhu pada sistem syaraf, dan meningkatkan aliran darah dalam sirkulasi tubuh (Diego MA, Field T, Hernandez-Reif M (2008) dalam Kaushik, 2010).

Perawatan metode kanguru merupakan perawatan bayi premature atau bayi berat lahir rendah dengan meletakkan bayi diantara kedua payudara ibu sehingga terjadi kontak langsung kulit ibu ke kulit bayi (Oktiawati \& Julianti, 2017). Terdapat dua jenis perawatan metode kanguru yaitu intermiten dan kontinu. Metode intermiten biasanya dilakukan di fasilitas unit perawatan khusus dan intensif, tidak dilakukan sepanjang waktu tapi minimal 60 menit, dilakukan ketika orang tua atau keluarga berkunjung, bisa dimulai pada bayi yang masih dalam proses pengobatan. Metode kontinu bisa dilakukan di unit rawat gabung atau dirumah, diberikan sepanjang waktu, dan bayi harus bebas dari gangguan nafas (Maryunani, 2013).

Menurut Kementerian Kesehatan (2012) prosedur perawatan metode kanguru adalah Bayi telanjang dada (hanya memakai popok, topi, kaos tangan, kaos kaki), diletakkan telungkup didada ibu dengan posisi tegak atau diagonal. Tubuh bayi memempel atau kontak langsung dengan ibu. Atur posisi kepala, leher, dan badan dengan baik untuk menghindari terhalangnya jalan napas. Kepala menoleh kesamping dibawah dagu ibu (ekstensi ringan). Tangan dan kaki bayi dalam keadaan fleksi seperti posisi "katak". Kemudian "fiksasi" dengan selendang. Ibu mengenakan pakaian atau blus longgar sehingga bayi berada dalam satu pakaian dengan ibu. Jika perlu, gunakan selimut. 
Bayi yang dirawat didalam inkubator akan mendapatkan kehangatan melalui perpindahan panas melalui konduksi dan radiasi. Perawatan metode kanguru memiliki mekanisme kerja seperti perawatan dalam inkubator. Perpindahan panas secara konduksi terjadi ketika kontak langsung kulit ibu dan bayi. Sedangkan perpindahan panas secara radiasi yakni ketika bayi dan ibu dalam satu selimut atau baju khusus (Thukral,Chawla, Agarwal, Deorari, dan Paul (2008) dalam Sari, Wardani, \& Arismawati, 2018).

\section{METODE}

Jenis penelitian ini ialah quasi experiment dengan design penelitian pre test and post test designs with two comparism treatment. Penelitian ini dilakukan di RSD Idaman Kota Banjarbaru dari tanggal 1 Oktober sampai 30 Nopember 2019. Pengambilan sampel menggunakan teknik accidental sampling. Kriteria inklusi yaitu bayi dengan usia gestasi $<37$ minggu, berat badan < 2500 gram, dirawat didalam inkubator dengan pengaturan suhunya telah disesuaikan umur gestasi dan berat badan bayi, hasil pengukuran heart rate $140-160 \mathrm{x} / \mathrm{mnt}$, respiratory rate : 40-60 $\mathrm{x} / \mathrm{mnt}$. Kriteria eksklusi yaitu bayi yang mengalamasi gangguan nafas, ada kelainan kongenital, terpasang IV line, suhu tubuh $>37^{\circ} \mathrm{C}$, ibu bayi mengalami baby blues (khusus intervensi perawatan metode kanguru), orang tua atau anggota keluarga yang akan melakukan perawatan metode kanguru sedang demam. Dari kriteria tersebut didapatkan 30 responden, 15 responden perlakuan terapi sentuhan, dan 15 responden perawatan metode kangguru. Thermometer yang digunakan untuk mengukur suhu adalah termometer Infrared Carezoe model KD3356. Uji stastistik yang digunakan yakni uji t dependen dan independen.

Bayi dipilih dengan teknik selang seling untuk menentukan jenis perlakuan. Proses penelitian dilakukan dengan cara mengukur suhu tubuh sebelum perlakuan, yaitu 3 menit setelah bayi dikeluarkan dari inkubator. Selanjutnya bayi akan diberikan perlakuan terapi sentuhan selama 15 menit atau perawatan metode kanguru. Pengukuran suhu sesudah dilakuka setelah 3 menit perlakuan berakhir.

\section{Hasil \\ Suhu tubuh sebelum perlakuan terapi sentuhan}

Tabel 4. 1

\begin{tabular}{cccccc}
\multicolumn{5}{c}{ Distribusi Suhu Tubuh Sebelum Perlakuan Terapi Sentuhan } \\
\hline Variabel & Mean & $\begin{array}{c}\text { Media } \\
\mathrm{n}\end{array}$ & $\begin{array}{c}\text { Std. } \\
\text { Deviation }\end{array}$ & $\begin{array}{c}\text { Minimal- } \\
\text { maximal }\end{array}$ & $95 \% \mathrm{Cl}$ \\
\hline $\begin{array}{c}\text { Suhu tubuh } \\
\text { sebelum } \\
\text { terapi }\end{array}$ & 36,79 & 36,90 & 0,233 & $36,40-$ & $36,66-$ \\
sentuhan & & & & 37,00 & 36,92 \\
& & & & &
\end{tabular}

Berdasarkan tabel 4.1 didapatkan rata-rata suhu tubuh sebelum perlakuan terapi sentuhan $36,79{ }^{\circ} \mathrm{C}$, median $36,90^{\circ} \mathrm{C}(95 \% \mathrm{Cl}: 36,66-36,92)$ dengan standar deviasi 0,233 ${ }^{\circ} \mathrm{C}$. Suhu tubuh terendah $36,40^{\circ} \mathrm{C}$ dan suhu tubuh tertinggi $37^{\circ} \mathrm{C}$. Dari estimasi interval disimpulkan bahwa $95 \%$ diyakini bahwa rata-rata suhu tubuh sebelum perlakuan terapi sentuhan adalah diantara $36,66{ }^{\circ} \mathrm{C}$ sampai dengan $36,92{ }^{\circ} \mathrm{C}$. 


\section{a. Suhu tubuh sesudah perlakuan terapi sentuhan}

Tabel 4.2

\begin{tabular}{cccccc}
\multicolumn{5}{c}{ Distribusi Suhu Tubuh Sesudah Perlakuan Terapi Sentuhan } \\
\hline Variabel & Mean & $\begin{array}{c}\text { Media } \\
\mathrm{n}\end{array}$ & $\begin{array}{c}\text { Std. } \\
\text { Deviation }\end{array}$ & $\begin{array}{c}\text { Minimal- } \\
\text { maximal }\end{array}$ & $95 \% \mathrm{Cl}$ \\
\hline $\begin{array}{c}\text { Suhu tubuh } \\
\text { setelah } \\
\text { terapi }\end{array}$ & 36,96 & 37,00 & 0,238 & $\begin{array}{c}36,60- \\
37,40\end{array}$ & $36,83-$ \\
sentuhan & & & & & \\
\hline
\end{tabular}

Berdasarkan tabel 4.2 didapatkan rata-rata suhu tubuh sesudah perlakuan terapi sentuhan $36,96{ }^{\circ} \mathrm{C}$,median $37^{\circ} \mathrm{C}(95 \% \mathrm{Cl}: 36,83-37,09)$ dengan standar deviasi $0,238^{\circ} \mathrm{C}$. Suhu tubuh terendah $36,60^{\circ} \mathrm{C}$ dan suhu tubuh tertinggi $37,40{ }^{\circ} \mathrm{C}$. Dari estimasi interval disimpulkan bahwa $95 \%$ diyakini bahwa rata-rata suhu tubuh sesudah perlakuan terapi sentuhan adalah diantara $36,83{ }^{\circ} \mathrm{C}$ sampai dengan $37,09^{\circ} \mathrm{C}$.

\section{b. Suhu tubuh sebelum perlakuan perawatan metode kanguru}

Tabel 4.3

Distribusi Suhu Tubuh Sebelum Perlakukan Perawatan Metode Kanguru

\begin{tabular}{cccccc}
\hline Variabel & Mean & $\begin{array}{c}\text { Media } \\
\mathrm{n}\end{array}$ & $\begin{array}{c}\text { Std. } \\
\text { Deviation }\end{array}$ & $\begin{array}{c}\text { Minimal- } \\
\text { maximal }\end{array}$ & $95 \% \mathrm{Cl}$ \\
\hline $\begin{array}{c}\text { Suhu tubuh } \\
\text { sebelum }\end{array}$ & & & & & \\
$\begin{array}{c}\text { perawatan } \\
\text { metode } \\
\text { kanguru }\end{array}$ & 36,67 & 36,70 & 0,287 & $36,10-$ & $36,51-$ \\
& & & & 37,00 & 36,83 \\
\end{tabular}

Berdasarkan tabel 4.3 didapatkan rata-rata suhu tubuh sebelum perlakuan perawatan metode kanguru $36,67{ }^{\circ} \mathrm{C}$,median $36,70{ }^{\circ} \mathrm{C}(95 \% \mathrm{Cl}: 36,51-36,83)$ dengan standar deviasi $0,287^{\circ} \mathrm{C}$. Suhu tubuh terendah $36,10^{\circ} \mathrm{C}$ dan suhu tubuh tertinggi $37^{\circ} \mathrm{C}$. Dari estimasi interval disimpulkan bahwa 95\% diyakini bahwa rata-rata suhu tubuh sebelum perlakuan perawatan metode kanguru adalah diantara $36,51^{\circ} \mathrm{C}$ sampai dengan 36,83 ${ }^{\circ} \mathrm{C}$. 


\section{c. Suhu tubuh sesudah perlakukan perawatan metode kanguru}

Tabel 4.4

Distribusi Suhu Tubuh Sesudah Perlakuan Perawatan Metode Kanguru

\begin{tabular}{cccccc}
\hline Variabel & Mean & $\begin{array}{c}\text { Media } \\
\mathrm{n}\end{array}$ & $\begin{array}{c}\text { Std. } \\
\text { Deviation }\end{array}$ & $\begin{array}{c}\text { Minimal- } \\
\text { maximal }\end{array}$ & $95 \% \mathrm{Cl}$ \\
\hline $\begin{array}{c}\text { Suhu tubuh } \\
\text { setelah }\end{array}$ & & & & & \\
$\begin{array}{c}\text { perawatan } \\
\text { metode } \\
\text { kanguru }\end{array}$ & 36,99 & 37,10 & 0,267 & $36,50-$ & $36,84-$ \\
& & & & 37,40 & 37,13 \\
\hline
\end{tabular}

Berdasarkan tabel 4.4 didapatkan rata-rata suhu tubuh sesudah perlakuan perawatan metode kanguru $36,99^{\circ} \mathrm{C}$,median $37,10^{\circ} \mathrm{C}(95 \% \mathrm{Cl}: 36,84-37,13)$ dengan standar deviasi $0,267{ }^{\circ} \mathrm{C}$. Suhu tubuh terendah $36,50{ }^{\circ} \mathrm{C}$ dan suhu tubuh tertinggi $37,40{ }^{\circ} \mathrm{C}$. Dari estimasi interval disimpulkan bahwa $95 \%$ diyakini bahwa rata-rata suhu tubuh sesudah perlakuan perawatan metode kanguru adalah diantara $36,84^{\circ} \mathrm{C}$ sampai dengan $37,13^{\circ} \mathrm{C}$.

\section{d. Perubahan suhu tubuh sebelum dan sesudah perlakukan terapi sentuhan}

Tabel 4.5

Distribusi Perubahan Suhu Tubuh Sebelum Dan Sesudah Perlakukan Terapi Sentuhan

\begin{tabular}{cccccc}
\hline Variabel & Mean & Median & $\begin{array}{c}\text { Std. } \\
\text { Deviation }\end{array}$ & $\begin{array}{c}\text { Minimal- } \\
\text { maximal }\end{array}$ & $95 \% \mathrm{Cl}$ \\
\hline $\begin{array}{c}\text { Perubahan } \\
\text { suhu terapi } \\
\text { sentuhan }\end{array}$ & 0,17 & 0,20 & 0,110 & $0,00-0,40$ & $\begin{array}{c}0,11- \\
0,23\end{array}$ \\
\hline
\end{tabular}

Berdasarkan tabel 4.5 didapatkan rata-rata perubahan suhu tubuh sebelum dan setelah perlakuan terapi sentuhan $0,17^{\circ} \mathrm{C}$, median $0,20{ }^{\circ} \mathrm{C}(95 \% \mathrm{Cl}: 0,11-0,23)$ dengan standar deviasi $0,110{ }^{\circ} \mathrm{C}$. Nilai perubahan suhu terendah $0{ }^{\circ} \mathrm{C}$ dan nilai perubahan suhu tertinggi $0,40{ }^{\circ} \mathrm{C}$. Dari estimasi interval disimpulkan bahwa 95\% diyakini bahwa rata-rata perubahan suhu tubuh sebelum dan sesudah perlakuan terapi sentuhan adalah diantara $0,11^{\circ} \mathrm{C}$ sampai dengan $0,23^{\circ} \mathrm{C}$. 


\section{e. Perubahan suhu tubuh sebelum dan sesudah perlakukan perawatan metode kanguru}

Tabel 4.6

\begin{tabular}{cccccc}
\multicolumn{5}{c}{ Distribusi Perubahan Suhu Tubuh Sebelum Dan Sesudah Perawatan } \\
Metode Kanguru \\
\hline Variabel & Mean & $\begin{array}{c}\text { Media } \\
\mathrm{n}\end{array}$ & $\begin{array}{c}\text { Std. } \\
\text { Deviation }\end{array}$ & $\begin{array}{c}\text { Minimal- } \\
\text { maximal }\end{array}$ & $95 \% \mathrm{Cl}$ \\
\hline $\begin{array}{c}\text { Perubahan } \\
\text { suhu } \\
\text { perawatan } \\
\text { metode } \\
\text { kanguru }\end{array}$ & 0,32 & 0,30 & 0,161 & $0,10-0,70$ & $0,23-$ \\
& & & & & 0,41 \\
\end{tabular}

Berdasarkan tabel 4.6 didapatkan rata-rata perubahan suhu tubuh sebelum dan setelah perlakuan perawatan metode kanguru $0,32{ }^{\circ} \mathrm{C}$, median $0,30{ }^{\circ} \mathrm{C}(95 \% \mathrm{Cl}: 0,23-0,41)$ dengan standar deviasi $0,161{ }^{\circ} \mathrm{C}$. Nilai perubahan suhu terendah $0,10{ }^{\circ} \mathrm{C}$ dan nilai perubahan suhu tertinggi $0,70{ }^{\circ} \mathrm{C}$. Dari estimasi interval disimpulkan bahwa $95 \%$ diyakini bahwa rata-rata perubahan suhu tubuh sebelum dan sesudah perlakuan perawatan metode kanguru adalah diantara $0,23^{\circ} \mathrm{C}$ sampai dengan $0,41^{\circ} \mathrm{C}$.

\section{f. Analisa Suhu Tubuh Sebelum Dan Sesudah Perlakukan Terapi Sentuhan}

Tabel 4.7

Distribusi Rata-Rata Suhu Tubuh Sebelum Dan Sesudah Perlakuan Terapi

Sentuhan

\begin{tabular}{|c|c|c|c|c|c|}
\hline Variabel & Mean & $\begin{array}{c}\text { Std. } \\
\text { Deviati } \\
\text { on }\end{array}$ & Std. Error & $P$ value & $\mathrm{N}$ \\
\hline $\begin{array}{l}\text { Suhu tubuh } \\
\text { sebelum } \\
\text { terapi } \\
\text { sentuhan }\end{array}$ & 36,79 & 0,233 & 0,060 & \multirow{2}{*}{0,0001} & 15 \\
\hline $\begin{array}{l}\text { Suhu tubuh } \\
\text { setelah } \\
\text { terapi } \\
\text { sentuhan }\end{array}$ & 36,96 & 0,238 & 0,62 & & 15 \\
\hline
\end{tabular}

Berdasarkan tabel 4.7 didapatkan bahwa rata-rata suhu tubuh sebelum perlakuan terapi sentuhan adalah $36,79{ }^{\circ} \mathrm{C}$ dengan standar deviasi $0,233{ }^{\circ} \mathrm{C}$. Sesudah perlakuan terapi sentuhan rata-rata suhu tubuh adalah $36,96{ }^{\circ} \mathrm{C}$ dengan standar 
deviasi $0,238^{\circ} \mathrm{C}$. Terlihat nilai mean perbedaan suhu tubuh sebelum dan sesudah perlakuan adalah 0,17 dengan standar deviasi 0,110 . Hasil uji statistik didapatkan nilai $p=0,0001$ maka dapat disimpulkan bahwa terapi sentuhan efektif meningkatkan suhu tubuh bayi berat lahir rendah.

\section{g. Analisa Suhu Tubuh Sebelum Dan Sesudah Perlakukan Perawatan Metode Kanguru}

Tabel 4.8

Distribusi Rata-Rata Suhu Tubuh Sebelum Dan Sesudah Perlakuan Perawatan Metode Kanguru

Berdasarkan tabel 4.8 didapatkan bahwa rata-rata suhu tubuh sebelum perlakuan perawatan metode kanguru adalah $36,67^{\circ} \mathrm{C}$ dengan standar deviasi $0,287^{\circ} \mathrm{C}$. Sesudah perlakuan perawatan metode kanguru rata-rata suhu tubuh adalah $36,99{ }^{\circ} \mathrm{C}$ dengan standar deviasi $0,267{ }^{\circ} \mathrm{C}$. Terlihat nilai mean perbedaan suhu tubuh sebelum dan sesudah perlakuan adalah 0,32 dengan standar deviasi 0,161. Hasil uji statistik didapatkan nilai $p=0,0001$ maka dapat disimpulkan bahwa perawatan metode kanguru efektif meningkatkan suhu tubuh bayi berat lahir rendah. 


\section{h. Analisa Perbedaan Efektivitas Terapi Sentuhan Dan Perawatan Metode Kanguru Terhadap Peningkatan Suhu Tubuh}

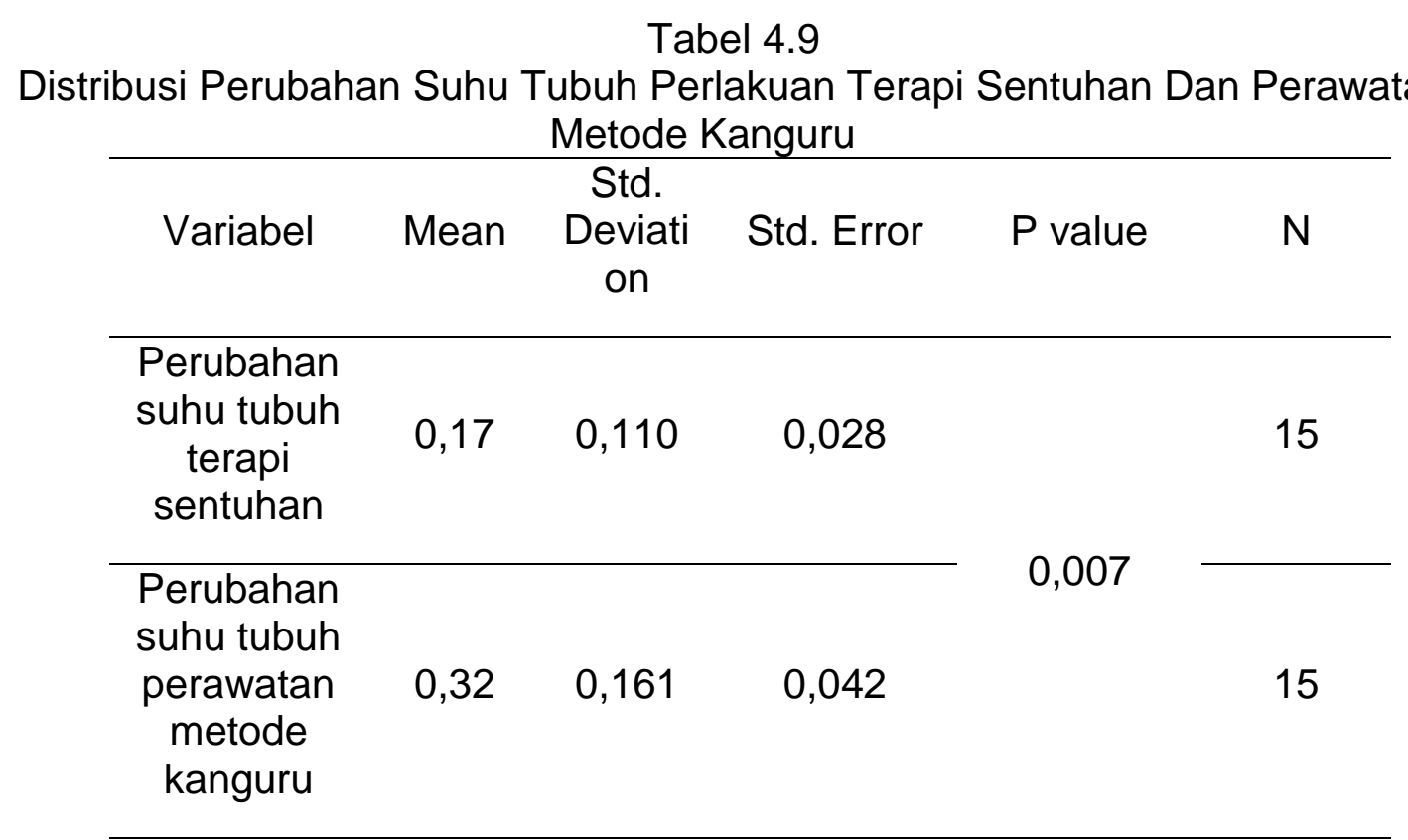

Berdasarkan tabel 4.9 didapatkan bahwa rata-rata perubahan suhu tubuh dengan perlakuan terapi sentuhan adalah $0,17^{\circ} \mathrm{C}$ dengan standar deviasi $0,110^{\circ} \mathrm{C}$, sedangkan untuk perlakuan perawatan metode kanguru rata-rata perubahan suhu tubuhnya adalah $0,32{ }^{\circ} \mathrm{C}$ dengan standar deviasi $0,161^{\circ} \mathrm{C}$. Hasil uji statistik didapatkan nilai $\mathrm{p}=0,007$, berarti pada alpha $<0,05$ terlihat ada perbedaan signifikan rata-rata perubahan suhu tubuh perlakuan terapi sentuhan dengan perawatan metode kanguru. Sehingga dapat disimpulkan bahwa perawatan metode kanguru lebih efektif meningkatkan suhu tubuh bayi berat lahir rendah dibandingkan terapi sentuhan.

\section{PEMBAHASAN}

Berdasarkan tabel 4.1 didapatkan bahwa rata-rata suhu tubuh sebelum perlakuan terapi sentuhan adalah $36,79^{\circ} \mathrm{C}$ dengan standar deviasi $0,233^{\circ} \mathrm{C}$. Sesudah perlakuan terapi sentuhan seperti terlihat pada table 4.2 rata-rata suhu tubuh adalah $36,96{ }^{\circ} \mathrm{C}$ dengan standar deviasi $0,238^{\circ} \mathrm{C}$. Terlihat nilai mean perbedaan suhu tubuh sebelum dan sesudah perlakuan adalah 0,17 dengan standar deviasi 0,110 dan nilai $p=0,0001$. Hal tersebut sejalan dengan penelitian yang dilakukan oleh Ningsih (2017) dengan sampel penelitian terdiri dari 27 bayi prematur di ruang perinatologi RSUD Bangkinang yang diberikan terapi sentuhan tanpa ada grup kontrol. Hasil pengukuran suhu sebelum perlakuan $36,0633^{\circ} \mathrm{C}$ menjadi $36,5867^{\circ} \mathrm{C}$ setelah perlakuan. Hasil penelitian setelah dan sesudah intervensi rata-rata suhu $=0.5233^{\circ} \mathrm{C}$,Standar deviasi $=0.159$. Penelitian lain yang dilakukan oleh Bayomi \& El-nagger, (2016) memberikan intervensi terapi pijat pada 64 bayi prematur di Neonatal Intensive Care Units (NICU) di Maternity and Children Hospital, and Heraa General Hospital Makkah Al-Mukaramah. Hasil dari penelitian ini menunjukkan $p$ value $0,01 \leq 0,05$. 
Berdasarkan tabel 4.3 didapatkan bahwa rata-rata suhu tubuh sebelum perlakuan perawatan metode kanguru adalah $36,67^{\circ} \mathrm{C}$ dengan standar deviasi $0,287^{\circ} \mathrm{C}$. Sesudah perlakuan seperti terlihat pada table 4.4, perawatan metode kanguru rata-rata suhu tubuh adalah $36,99^{\circ} \mathrm{C}$ dengan standar deviasi $0,267^{\circ} \mathrm{C}$. Terlihat nilai mean perbedaan suhu tubuh sebelum dan sesudah perlakuan adalah 0,32 dengan standar deviasi 0,161 dan nilai $p=0,0001$. Hal tersebut sejalan dengan penelitian yang dilakukan oleh Sari, Wardani, \& Arismawati (2018) yang populasi dari penelitian ini adalah semua bayi berat lahir rendah di RS Wahidin Sudiro Husodo Mojokerto. Sample penelitian terdiri dari 123 bayi berat lahir rendah yang hasil penelitiannya hasil rata-rata kenaikan suhu $36{ }^{\circ} \mathrm{C}$ menjadi $36,2^{\circ} \mathrm{C}$. Sebuah penelitian meta analis oleh Boundy, Dastjerdi, Spiegelman, \& Wafaie, (2019) Dari 1035 jurnal yang diseleksi hanya 124 yang masuk kriteria. Penelitian tersebut menganalisa berbagai manfaat perawatan metode kanguru dari berbagai aspek, salah satunya adalah suhu tubuh. Dalam analisa tersebuh suhu tubuh rata-rata bayi yang mendapatkan perawatan metode kanguru adalah $0,24^{\circ} \mathrm{C}$ lebih tinggi dari bayi kelompok kontrol $(n=14 ; 95 \% \mathrm{Cl}, 0.15$ to $0.33 ; \mathrm{I} 2=82 \%)$.

Berdasarkan tabel 4.9 didapatkan bahwa rata-rata perubahan suhu tubuh dengan perlakuan terapi sentuhan adalah $0,17^{\circ} \mathrm{C}$ dengan standar deviasi $0,110^{\circ} \mathrm{C}$, sedangkan untuk perlakuan perawatan metode kanguru rata-rata perubahan suhu tubuhnya adalah $0,32^{\circ} \mathrm{C}$ dengan standar deviasi $0,042^{\circ} \mathrm{C}$ dan nilai $\mathrm{p}=0,007$. Sehingga ada beda efektif antar terapi sentuhan dan perawatan metode kanguru. Jika dilihat dari nilai rata-rata perubahan suhu perlakuan terapi sentuhan $0,17^{\circ} \mathrm{C}$ dan perlakuan perawatan metode kanguru sebesar $0,32{ }^{\circ} \mathrm{C}$ maka perawatan metode kanguru lebih efektif.

Peningkatan suhu terjadi pada bayi yang mendapatkan terapi sentuhan karena terjadi perpindahan panas secara konduksi melalui sentuhan tangan pemberi pijatan sehingga menurunkan kehilangan panas, memfasilitasi regulasi suhu pada sistem syaraf, dan meningkatkan aliran darah dalam sirkulasi tubuh (Diego MA, Field T, Hernandez-Reif M (2008) dalam Kaushik, 2010).

Bayi yang dirawat didalam inkubator akan mendapatkan kehangatan melalui perpindahan panas melalui konduksi dan radiasi. Perawatan metode kanguru memiliki mekanisme kerja seperti perawatan dalam inkubator. Perpindahan panas secara konduksi terjadi ketika kontak langsung kulit ibu dan bayi. Sedangkan perpindahan panas secara radiasi yakni ketika bayi dan ibu dalam satu selimut atau baju khusus (Thukral,Chawla, Agarwal, Deorari, dan Paul (2008) dalam Sari, Wardani, \& Arismawati, 2018). Penelitian yang dilakukan oleh Victoria Karlsson et al (2012) memaparkan bahwa kontak kulit antara orang tua dan bayi mampu mempertahankan suhu tubuh bayi. Perawatan metode kanguru mampu mengurangi kehilangan panas akibat terpaparnya permukaan kulit bayi terhadap lingkungan yang lebih dingin. Saat metode ini dilakukan akan terjadi perpindahan panas melalui sentuhan kulit orang tua ke bayi. Selama kontak kulit ke kuliat dilakukan, konduksi panas dari orang tua ke bayi cukup tinggi untuk mengimbangi kehilangan panas secara evaporasi dan konveksi.

\section{KESIMPULAN}

Hasil uji statitistik menunjukan $\mathrm{P}=0.007$ dengan alpha $<0,05$ yang artinya ada beda efektifitas. Rata-rata perubahan suhu tubuh dengan perlakuan terapi sentuhan adalah 0,17 oC sedangkan untuk perlakuan perawatan metode kanguru rata-rata perubahan suhu tubuhnya adalah $0,32 \mathrm{oC}$. sehingga perawatan metode kanguru lebih efektif dari 
terapi sentuhan untuk meningkatkan suhu tubuh. Hal tersebut dikarenakan mekanisme perpindahan panas perawatan metode kanguru lebih baik yakni terjadi dua mekanisme perpindahan panas yaitu konduksi dan radiasi. Sedangkan pada terapi sentuhan hanya terjadi mekanisme perpindana panas secara konduksi saja.

\section{DAFTAR PUSTAKA}

1. Aeda Ernawati. (2015). Jurnal Litbang Vol.XI, No.1, Juni 2015:46-55. INCIDENT DESCRIPTION OF LOW BIRTH WEIGHT IN PATI REGENCY, (1), 46-55.

2. Bayomi, O. R., \& El-nagger, N. S. (2016). Effect of applying massage therapy on physical, physiological and behavioral states of premature neonates, (July 2015). https://doi.org/10.5430/jnep.v5n10p105

3. Boundy, E. O., Dastjerdi, R., Spiegelman, D., \& Wafaie, W. (2019). Kangaroo Mother Care and Neonatal Outcomes: A Meta-analysis, 137(1).

4. Brostro, E. B., Sarman, I., \& Lindberg, L. (2009). The Stockholm Neonatal Family Centered Care Study: Effects on Length of Stay and Infant Morbidity. https://doi.org/10.1542/peds.2009-1511

5. Farhadi, R. (2014). Incidence of neonatal hypothermia at birth in hospitals of Islamic Republic of Iran : A review, 2(2), 21-30. https://doi.org/10.7508/JPR-V2-N2-21-30

6. Frey, H. A., \& Klebanoff, M. A. (2016). Seminars in Fetal \& Neonatal Medicine The epidemiology, etiology, and costs of preterm birth. Seminars in Fetal and Neonatal Medicine, 10-15. https://doi.org/10.1016/j.siny.2015.12.011

7. Kaushik, J. S. (2010). Massage and Touch Therapy in Neonates: The Current Evidence, (December 2013). https://doi.org/10.1007/s13312-010-0114-2

8. Kementerian, K. (2012). Buku Saku Pelayanan Kesehatan Neonatal Esensial. Jakarta: Direktorat Bina Kesehatan Anak Kemenkes RI.

9. Kementerian, K. (2018). Riset Kesehatan Dasar 2018. Jakarta: Badan Penelitian dan Pengembangan Kesehatan, Kemenkes RI.

10. Lissauer, T., \& Fanaroff, A. A. (2013). Selayang Neonatologi (Kedua). Jakarta: PT. Indeks.

11. Maryunani, A. (2013). Asuhan Bayi Dengan Berat Badan Lahir Rendah. Jakarta: CV. Trans Info Media.

12. Mccowan, L., \& Horgan, R. P. (2009). Best Practice \& Research Clinical Obstetrics and Gynaecology Risk factors for small for gestational age infants. Best Practice \& Research Clinical Obstetrics \& Gynaecology, 23(6), 779-793. https://doi.org/10.1016/j.bpobgyn.2009.06.003

13. Minguez-milio, J. A., Alcázar, J. L., Aubá, M., Ruiz-zambrana, Á., \& Minguez, J. (2011). Perinatal outcome and long-term follow-up of extremely low birth weight infants depending on the mode of delivery, 24(10), 1235-1238. https://doi.org/10.3109/14767058.2011.552990

14. Momeni M, Danaei M, Kermani AJ, Bakhshandeh M, Foroodnia S, Mahmoudabadi Z, Amirzadeh R, S. H. (2017). Prevalence and risk factors of low birth wlntake, M. F., Type, B., Lamp, J. M., \& Macke, J. K. (2010). After Birth, 169-177. https://doi.org/10.1111/j.1552-6909.2010.01106.xeight in the Southeast of Iran. Int J Prev Med, 8:12. 
15. Ningsih, N. F. (2017). Pengaruh Terapi Sentuhan Terhadap Suhu Tubuh Bayi. Jurnal Ners Universitas Pahlawan Tuanku Tambusai, 1(1).

16. Oktiawati, A., \& Julianti, E. (2017). Teori Dan Aplikasi Perawatan Bayi Prematur. Jakarta: CV. Trans Info Media.

17. Pongoh, A. (2019). THE EFFECT OF TOUCH THERAPY ON BODY TEMPERATURE IN NEWBORNS IN THE SELE BE SOLU HOSPITAL , SORONG CITY ,.. Public Health of Indonesia, 5(1), 18-24.

18. Potter, P. A., \& Perry, A. G. (2010). Fundamental Keperawatan (Edisi 7 Buku 2). Jakarta: Penerbit Salemba Medika.

19. Proverawati, A., \& Ismawati, C. (2010). Berat Badan Lahir Rendah. Yogyakarta: Nuha Medika.

20. Roesli, U. (2010). Pedoman Pijat Bayi Prematur dan Bayi Usia 0-3 Bulan. Jakarta: Trubus Agriwidya.

21. Sari, B. M., Wardani, R. A., \& Arismawati, D. F. (2018). THE EFFECT OF KANGURU MOTHER CARE METHOD TO CHANGE OF BODY TEMPERATURE IN LBW ( LOW BODY WEIGHT ) BABIES Dian Husada Institute of Health Science Mojokerto Introduction: Low Birth Weight Babies ( LBW ) are babies with birth weight less than 2500 grams reg. International Journal of Nursing and Midwifery Science, 2(2), 131-136.

22. United Nation Children's Fund (UNICEF), W. H. O. (WHO). (2019). UNICEF-WHO Low birthweight estimates: Levels and trends 2000-2015. Geneva: World Health Organization.

23. Vaughans, B. W. (2013). Keperawatan Dasar. Yogyakarta: Rapha Publishing.

24. Victoria Karlsson, RN, Ann-Britt Heinemann, RN, Gunnar Sj€ors, MD, PhD, Kerstin Hedberg Nykvist, RN, P., \& and Johan Agren, MD, P. (2012). Early Skin-to-Skin Care in Extremely Preterm Infants: Thermal Balance and Care Environment. The Journal Of Pediatrics. https://doi.org/10.1016/j.jpeds.2012.02.034

25. Yunanto, A. (2013). (2013). Panduan Praktik Klinik neonatologi. Malang: PT. Danar Wijaya. Malang: PT. Danar Wijaya.

26. Zheng, J., Xiao, X., Zhang, Q., Mao, L., Yu, M., \& Xu, J. (2015). The Placental Microbiome Varies in Association with Low Birth Weight in Full-Term Neonates, 6924-6937. https://doi.org/10.3390/nu7085315 